\title{
SKIN PRICK TEST VERSUS WESTERN BLOT SPECIFICITY AND SENSITIVITY FOR MUGWORT (ARTEMISIA) POLLEN SENSITIZATION DETERMINATION IN PATIENTS WITH RESPIRATORY ALLERGY
}

\author{
A. Ye. Bogomolov \\ National Pirogov Memorial Medical University, Vinnytsya
}

\begin{abstract}
Objective was to study and compare the parameters of the specificity and sensitivity of skin testing and serologic determination of specific mugwort IgE. Materials and methods. 88 patients with allergic rhinitis and / or asthma were examined by three different methods of specific allergic diagnosis (in vivo and in vitro) in accordance with the guidelines of the ethics committee of the National Pirogov memorial medical university, all were beyond the acute period. The inclusion criteria were allergic rhinitis diagnosis (both intermittent and persistent) andlor asthma with proven sensitivity to pollen allergens. Skin prick test was carried out according to the classical testing procedure in accordance with regulatory documents with commercial extracts of allergens. Western blot testing for specific IgE levels was performed using RIDA qLine test systems (R-Biopharm AG, Darmstadt, Germany) and Euroline (Euroimmun). The sIgE concentration was converted to a nominal scale (grades) according to the following rules: < $0.35 \mathrm{IU}$ mL-1-level 0 (negative), (0.36-0.69) IU mL-1-level 1 (boundary levels), (0.7-3.49) IU mL-1-level 2 (slightly elevated), (3.50-17.4) IU mL-1-level 3 (moderately elevated), (17.5-49.9) IU mL-1-level 4 (high levels), (50-100) IU mL-1-level 5 (very high levels) and > 100 IU mL-1-level 6 (extremely high levels). Results and discussion. The systematic error of the measurement results was $-3.01 \mathrm{ku} / 1$, which indicates the presence of a systematic difference. The distribution graph corresponds to the type of graphs of absolute systematic error. The standard deviation of the difference was 15.5 , which is significant compared to the values themselves, there is no dependence of the measurement difference on the amount of specific IgE in the blood. In addition, part of the values does not fit within the confidence limits of $\pm 95 \%$. Thus, the results of the two systems for the determination of specific IgE for mugwort allergen by the Rida AllergyScreen and Euroline methods do not fully correspond due to the systematic divergence of indicators. There is good correspondence between the results of skin allergen testing and the detection of specific IgE by the Rida AllergyScreen method, and moderate correspondence between the results of skin allergen testing with the mugwort allergen and the detection of specific IgE by the Euroline method.
\end{abstract}

Key words: skin prick testing, allergy, western blot, IgE.

A. Ye. Bogomolov Candidate of Medical Sciences, Associate Professor of Phthisiology, Clinical Immunology and Allergy Department, Vinnytsya National Pirogov Memorial Medical University, 21000, Pirogova, 56, Vinnytsya, Ukraine, art.bogomolov@gmail.com Asthma and Allergy, 2019, 4, P. 50-54.

\section{РІЗНІ МЕТОДИ ВИЗНАЧЕННЯ СЕНСИБІЛІЗАЦІЇ ДО АЛЕРГЕНУ ПИЛКУ ПОЛИНУ (ARTEMISIA)У ПАЦІЄНТІВ 3 РЕСПІРАТОРНОЮ АЛЕРГІЄЮ}

\section{А. С. Богомолов}

Резюме. Метою дослідження було провести огляд літератури за тематикою діагностичної цінності різних методів визначення сенсибілізації у пацієнтів з алергією, вивчити параметри специфічності і чутливості шкірного тестування і лабораторного визначення специфічного IgE. Матеріали та методи. В ході дослідження 88 пацієнтів 3 алергічним ринітом та / або атопічною астмою були обстежені трьома різними методами специфічної алергічної діагностики (in vivo та in vitro). Критеріями включення були діагноз алергічного риніту (як інтермітуючого, так $\mathrm{i}$ персистуючого) та / або атопічної астми з доведеною чутливістю до пилкових алергенів. Прик-тест проводився за класичною методикою тестування відповідно до нормативних документів з комерційними екстрактами алергенів. Вестерн-блот для визначення рівні в IgE проводили з використанням тест-систем RIDA qLine (R-Biopharm AG, Дармштадт, Німеччина) i Euroline (Euroimmun). Концентрацію sIgЕ переводили в номінальну шкалу (оцінки)

(C) Bogomolov A. Ye., 2019

www.search.crossref.org

DOI: $10.31655 / 2307-3373-2019-4-50-54$ 
відповідно до наступних правил: < 0.35 MO мл-1-рівень 0 (негативний), (0,36-0,69 MO) мл-1-рівень 1 (граничні рівні), (0,7-3,49) IU mL-1-level 2 (злегка підвищений), (3,50-1,4) IU mL-1-level 3 (помірно підвищений), (17,5-49,9) IU mL-1-level 4 (високі рівні), (50-100) MO мл-1-рівня 5 (дуже високі рівні) і > 100 МО мл-1-рівня 6 (дуже високі рівні). Результати та обговорення. Систематична похибка результатів вимірювань дорівнює -3,01 ku/l, що свідчить про присутність систематичного розходження. При цьому графік розподілу відповідає типу графіків абсолютної систематичної помилки. Стандартне відхилення різниць склало 15,5, що суттєво у порівнянні 3 самими значеннями, немає залежності різниці вимірювань від кількості специфічних IgE у крові. Крім того, частина значень не вкладаються у межі довірчого інтервалу \pm 95 \%. Результати двох систем визначення специфічного IgE до алергену полину методами Rida Allergy Screen та Euroline не дуже добре узгоджуються між собою внаслідок систематичного розходження показників. Між даними шкірного тестування з алергенами полину та виявленням специфічного IgE методом Rida Allergy Screen є добра погодженість між результатами досліджень, між даними шкірного тестування з алергеном полину та виявленням специфічного IgE методом Euroline присутня помірна погодженість між результатами досліджень.

Ключові слова: прик-тест, алергія, імуноблотинг, IgE.

А. Є. Богомолов

Канд. мед. наук, дочент

Вінницький національний медичний університет ім. М.І. Пирогова вул. Пирогова, 56, м. Вінниия, Україна, 21000 e-mail: art.bogomolov@gmail.com

Астма та алергія. 2019, № 4, С. 50-54.

\section{РАЗЛИЧНЫЕ МЕТОДЫ ОПРЕДЕЛЕНИЯ СЕНСИБИЛИЗАЦИИ К ПЫЛЬЦЕВОМУ АЛЛЕРГЕНУ ПОЛЫНИ (ARTЕМISIA) У ПАЦИЕНТОВ С РЕСПИРАТОРНОЙ АЛЛЕРГИЕЙ}

\section{А. Е. Богомолов}

Резюме. Целью исследования было провести обзор литературы по тематике диагностической ценности различных методов определения сенсибилизации у пациентов с аллергией, изучить параметры специфичности и чувствительности кожного тестирования и лабораторного определения специфического IgE. Maтериаль и методы. В ходе исследования 88 пациентов с аллергическим ринитом и / или астмой были обследованы тремя различными методами специфической аллергической диагностики (in vivo и in vitro). Критериями включения были диагноз аллергического ринита (как интермиттирующего, так и персистирующего) и / или астмы с доказанной чувствительностью к пыльцевым аллергенам. Прик-тест проводился по классической методике тестирования в соответствии с нормативными документами с коммерческими экстрактами аллергенов. Вестерн-блоттинг для определения уровней IgE проводили с использованием тест-систем RIDA qLine (R-Biopharm AG, Дармштадт, Германия) и Euroline (Euroimmun). Концентрацию SIgE переводили в номинальную шкалу (оценки) в соответствии со следующими правилами: $<0,35 \mathrm{ME}$ мл-1-уровень 0 (отрицательный), (0,36-0,69 ME) мл-1-уровень 1 (граничные уровни), (0,7-3,49) IU mL-1-level 2 (слегка повышенный), (3,50-17,4) IU mL-1-level 3 (умеренно повышенный), (17,5-49,9) IU mL-1-level 4 (высокие уровни), (50100) МЕ мл-1-уровня 5 (очень высокие уровни) и > 100 МЕ мл-1-уровня 6 (очень высокие уровни). Результаты $u$ обсуждение. Систематическая погрешность результатов измерений равна -3,01 ku / 1, что свидетельствует о присутствии систематического различия. При этом график распределения соответствует типу графиков абсолютной систематической ошибки. Стандартное отклонение разниц составил 15,5, что существенно по сравнению с самыми значениями, нет зависимости разницы измерений от количества специфических IgE в крови. Кроме того, часть значений не укладываются в границы доверительного интервала \pm 95 \%. Результаты двух систем определения специфического IgE к аллергену полыни методами Rida Allergy Screen и Euroline не очень хорошо согласуются между собой в результате систематического различия показателей. Между данными кожного тестирования с аллергенами полыни и выявлением специфического IgE методом Rida Allergy Screen есть хорошая согласованность между результатами исследований, между данными кожного тестирования с аллергеном полыни и выявлением специфического IgE методом Euroline присутствует умеренная согласованность между результатами исследований.

Ключевые слова: прик-тест, аллергия, иммуноблоттинг, IgE.

А. Е. Богомолов

Канд. мед. наук, доцент

Винницкий национальный медицинский университет им. Н. И. Пирогова ул. Пирогова, 56, г. Винница, Украина, 21000 e-mail: art.bogomolov@gmail.com

Астма и аллергия. 2019, № 4, С. 50-54. 
Artemisia is one the most important outdoor allergen throughout Ukraine. It can cause allergic rhinitis, asthma, or both of them. Artemisia species, or mugwort, is an anemophilous genus included in the Compositae family. Since it was verified as an allergenic pollen in 1960, pollen from the various Artemisia species is one of the most frequent and serious causes of pollinosis worldwide $[1,2]$. The genus Artemisia includes 57 species in Europe [3, 5-8].

Different diagnostic tools are available in clinical practice to detect sensitization in patients with respiratory allergy. As we showed before [4], different diagnostic parameters of skin prick test (SPT) and serological methods are typical for $D$. pteronyssinus, D. farinae sensitization. Below we present the data of our research in patients with allergic rhinitis and asthma in 20152018.

Materials and methods. In this study 88 patients with allergic rhinitis and/or atopic asthma were examined by three different methods of specific allergic diagnosis (in vivo and in vitro). The inclusion criteria were allergic rhinitis diagnosis (both intermittent and persistent) or atopic asthma with proven sensitivity to mugwort allergens. SPT was carried out according to the classical testing procedure in accordance with regulatory documents with commercial extracts of allergens (Immunolog, Vinnitsa, Ukraine). For the test, a positive (histamine dihydrochloride solution $0.01 \%$ - Solutio histamini dihydrochloridi $0.01 \%$ pro diagnostica cutanea morborum allergicorum) and negative (sodium chloride, disodium phosphate dodecahydrate (sodium phosphate dibasic), potassium dihydrogen phosphate (potassium phosphate monosubent phenol, tween 80 , water for injection) controls (Immunolog, Vinnitsa, Ukraine) were used. SPT results were assessed in 15 min visually using a ruler in $\mathrm{mm}$ and were classified according to the existing scale as negative, doubtful, weak $(+)$, strong $(++)$ and very strong $(++)$.

A standard medical interview and the qualification of patient were performed during an earlier visit, and then, $15 \mathrm{~mL}$ of blood for the sIgE test was collected. Western blot testing for specific IgE levels was performed using RIDA qLine test systems (R-Biopharm AG, Darmstadt, Germany) and Euroline (Euroimmun) system. The sIgE concentration was converted to a nominal scale (grades) according to the following rules: < $0.35 \mathrm{IU}$ mL-1-level 0 (negative), (0.36-0.69) IU mL1-level 1 (boundary levels), (0.7-3.49) IU mL-1-level 2 (slightly elevated), (3.50-17.4) IU mL-1-level 3 (moderately elevated), (17.5-49.9) IU mL-1-level 4 (high levels), (50-100) IU mL-1-level 5 (very high levels) and > 100 IU mL-1-level 6 (extremely high levels).

Results. In the process of this study, three different methods of specific allergic diagnosis (in vivo and in vitro) were used to examine 88 patients with asthma and allergic rhinitis. Among these patients, sensitization to the allergen was $27.3 \%$ (24 patients) by skin prick test, specific IgE by Rida AllergyScreen were found in $36.3 \%$ (32 patients) and the presence of specific IgE by Euroline was detected in $20.4 \%$ (18 patients).

In Table 1 the results of the comparison of Rida AllergyScreen to the mugwort with the data prick test method are presented. Comparing two different types of specific allergic diagnosis by the method of establishing the correlation relations with mugwort, the dominance of the elements of the main diagonal is noted, indicating a close coincidence of the results of two different methods (validity coincidence of results was $90.9 \%-80$ cases).

Ta b l e 1. Sensitization to mugwort by the results of skin testing and the detection of specific IgE by Rida AllergyScreen

\begin{tabular}{l|c|c|c|c}
\hline \multirow{2}{*}{ Prick test } & \multicolumn{3}{|c|}{ Specific lgE (ku/l) } & \multirow{2}{*}{ Total } \\
\cline { 2 - 4 } & $\begin{array}{c}<0.35 \\
\text { (negative) }\end{array}$ & $\begin{array}{c}0.35-0.7 \\
\text { (questionable) }\end{array}$ & $\begin{array}{c}>0.7 \\
\text { (positive) }\end{array}$ & \\
\hline $\begin{array}{l}\text { Papule } 0 \mathrm{~mm} \\
\text { (negative result) }\end{array}$ & 56 & 0 & 8 & 64 \\
$\begin{array}{l}\text { Papule } 1-2 \mathrm{~mm} \\
\text { (questionable result) }\end{array}$ & 0 & 0 & 0 & 0 \\
$\begin{array}{l}\text { Papule } \geq 3 \mathrm{~mm} \\
\text { (positive result) }\end{array}$ & 0 & 0 & 24 & 24 \\
Total & 56 & 0 & 32 & 88 \\
\hline
\end{tabular}

The results of two different methods of specific diagnostics to determine allergic sensitization to mugwort are almost similar, but there is a certain asymmetry of the differences in the results of skin testing by the blind test method and the determination of specific IgE when one test gives negative results and the other one is positive or questionable.

To obtain conclusions about the reliability of this asymmetry, we conducted an in-depth statistical analysis of the correlation of laboratory allergic and skin tests. The analysis of harmony results of two different methods to determine the sensitization to mugwort through the construction of the confidence interval (Table 2) showed that the coefficient suggests a good correspondence $(r=0.792)$ of this two different tests. The limits of the $95 \%$ confidence interval (0.656-0.919) exclude zero, which indicates the accuracy of the match. The lower limit is in the range of good coherence, and the upper one is in the area of excellent coherence.

Table 2. The results of statistical estimation of the consistency of results of skin testing and the detection of specific IgE by the method of Rida AllergyScreen to determine sensitization to mugwort

\begin{tabular}{l|l}
\hline Kappa coefficient & 0.792 \\
\hline Asymptotic kappa error & 0.068 \\
\hline Lower border $95 \%$ confidence interval & 0.656 \\
\hline Upper boundary 95 \% confidence interval & 0.919 \\
\hline
\end{tabular}

A statistical evaluation of the null hypothesis lack of consistency of the results of two different methods of specific diagnostics to determine allergic sensitization to mugwort shown in Table 3. 
Ta b l e 3. The results of statistical estimation of the null hypothesis of the lack of consistency of results of skin testing and the detection of specific IgE by the method of Rida AllergyScreen for definition sensitization to mugwort

\begin{tabular}{l|c}
\hline Asymptotic kappa error for $H_{0}$, & 0.94 \\
\hline$Z$ & 7.599 \\
\hline One-way testing $\operatorname{Pr}>Z$ & $<0.001$ \\
\hline Two-sided testing $\operatorname{Pr}>|Z|$ & $<0.001$ \\
\hline
\end{tabular}

The hypothesis is rejected both in one-sided and bilateral tests, which testifies to the true consistency of both allergic tests.

That is to say, according to the data of skin testing with mugwort allergens and the detection of specific IgE by the Rida AllergyScreen has a good consistency between the results.

In Table 4 we showed the comparison of the presence of specific IgE to the mite mugwort by Euroline with skin prick testing test. Comparing two different types of specific diagnostics by setting correlative relationships to mugwort is noted the absence of the domination of the elements of the main diagonal, indicating a medium degree of coincidence of the results of two different methods (validity of the results was $81.8 \%-72$ cases).

The results of two different methods of specific allergic diagnosis to determine the sensitization to the mugwort allergy are closely identical, but there is a certain asymmetry of the differences in the results of
Ta b l e 4. Sensitization to mugwort by the results of skin testing and the detection of specific IgE by Euroline

\begin{tabular}{l|c|c|c|c}
\hline \multirow{2}{*}{ Prick test } & \multicolumn{3}{|c|}{ Specific lgE $(\mathrm{ku} / \mathrm{I})$} & \multirow{2}{*}{ Total } \\
\cline { 2 - 4 } & $\begin{array}{c}<0.35 \\
\text { (negative) }\end{array}$ & $\begin{array}{c}0.35-0.7 \\
\text { (questionable) }\end{array}$ & $\begin{array}{c}>0.7 \\
\text { (positive) }\end{array}$ & \\
\hline $\begin{array}{l}\text { Papule } 0 \mathrm{~mm} \\
\text { (negative result) }\end{array}$ & 58 & 2 & 4 & 64 \\
$\begin{array}{l}\text { Papule } 1-2 \mathrm{~mm} \\
\text { (questionable result) }\end{array}$ & 0 & 0 & 0 & 0 \\
$\begin{array}{l}\text { Papule } \geq 3 \mathrm{~mm} \\
\text { (positive result) }\end{array}$ & 8 & 2 & 14 & 24 \\
Total & 64 & 4 & 18 & 88 \\
\hline
\end{tabular}

skin testing by the blind test method and the determination of specific IgE blood when one test gives negative results and the other one is positive or doubtful.

To obtain conclusions about the reliability of this asymmetry, we conducted an in-depth statistical analysis of the correlation of laboratory allergic and skin tests. The analysis of harmony results of two different methods to determine the diagnosis of allergic sensitization to mugwort through the construction of the confidence interval (Table 5) showed that the coefficient suggests satisfactory agreement $(r=0.544)$ of the findings of the two different tests. The limits of the $95 \%$ confidence interval (0.369-0.719) exclude 0 , which indicates the accuracy of the match. The lower limit lies in the range of poor consistency, and the upper one is in the area of moderate coherence.

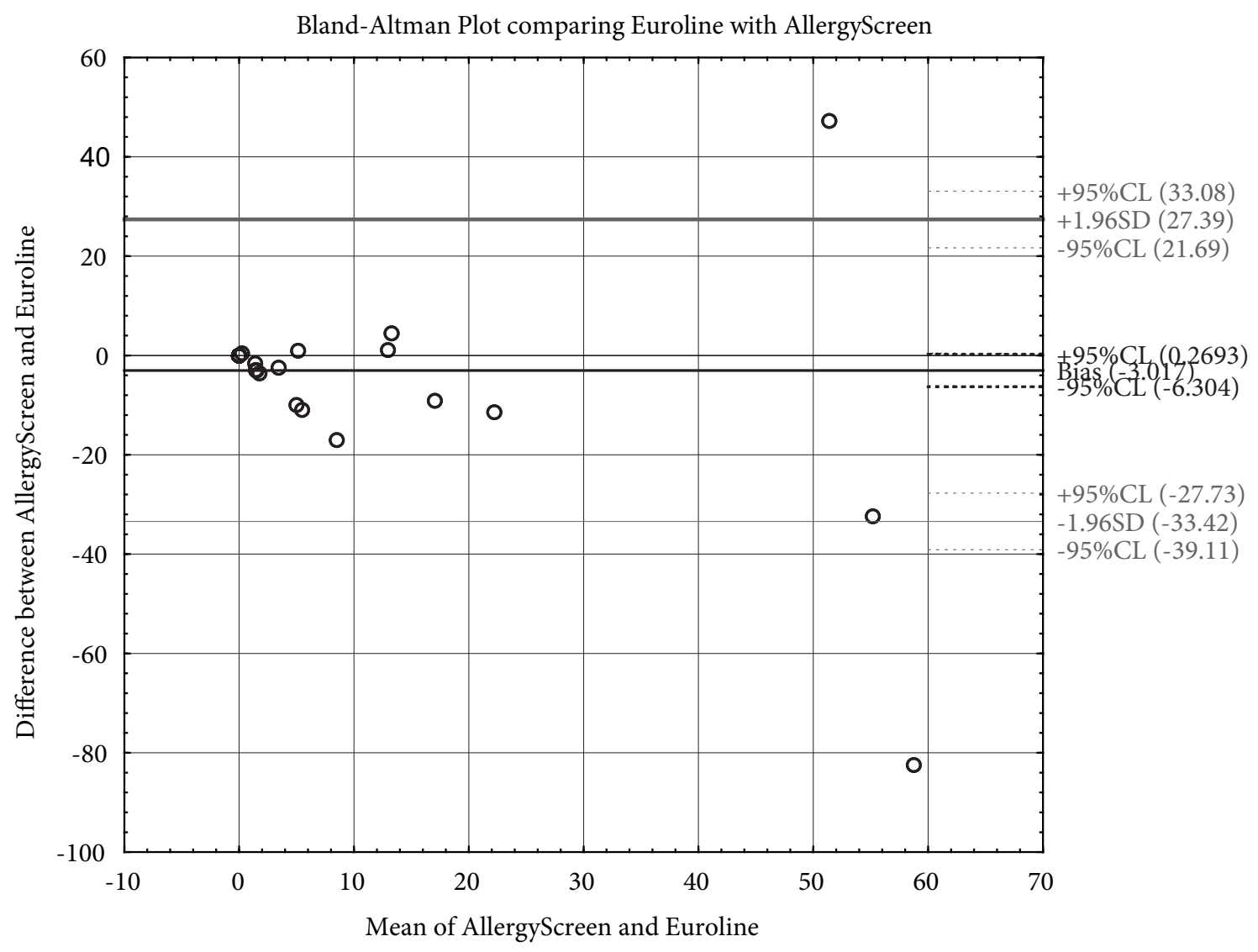

P i c t u r e 1. The Blend-Altman plot for Determining Specific IgE to mugwort by Rida AllergyScreen and Euroline. 
Ta b l e 5. The results of statistical estimation of the consistency of results of skin testing and the detection of specific IgE by the Euroline method to determine the sensitization to the mugwort allergen

\begin{tabular}{l|l}
\hline Kappa coefficient & 0.544 \\
\hline Asymptomatic kappa error & 0.094 \\
\hline Lower border 95 \% confidence interval & 0.369 \\
\hline Upper boundary 95 \% confidence interval & 0.719 \\
\hline
\end{tabular}

A statistical evaluation of the null hypothesis lack of consistency of the results of two different methods of specific diagnostics to determine Allergic sensitization to mugwort shown in table 6 .

Ta b l e 6. The results of statistical estimation of the null hypothesis of the lack of consistency of results of skin testing and the detection of specific IgE by the Euroline method for determination sensitization to the mugwort allergen

\begin{tabular}{l|c}
\hline Asymptotic kappa error for $H_{0^{\prime}}$ & 0.972 \\
\hline$Z$ & 5.637 \\
\hline One-way testing $\operatorname{Pr}>Z$ & $<0.05$ \\
\hline Two-sided testing $\operatorname{Pr}>|Z|$ & $<0.05$ \\
\hline
\end{tabular}

The hypothesis is not accepted either by one-sided, or by double-sided testing the loyalty to the consistency of the tests among themselves.

That is to say, according to the data of skin testing with allergens mugwort and the detection of specif-

\section{REFERENCES}

1. Rui Tang, Jin-Lu Sun, Jia Yin, Zhi Li. Artemisia Allergy Research in China. BioMed Research International. 2015:179426. doi: 10.1155/2015/179426.

2. D'Amato G, Spieksma FTM, Liccardi G, et al. Pollen-related allergy in Europe. Allergy. 1998;53(6):567-578. doi: 10.1111/j.1398-9995.1998.tb03932.x.

3. Spieksma FTM, Charpin H, Nolard N, Stix E. City spore concentrations in the European economic community (EEC). IV. Summer weed pollen (Rumex, Plantago, Chenopodiaceae, Artemisia), 1976 and 1977. Clin Allergy. 1980;10(3):31929. doi: 10.1111/j.1365-2222.1980.tb02114.x.

4. Bogomolov AYe. Diagnostic value of methods for sensitization determination in people with allergic rhinitis (review of literature and own data). Asthma and allergy. 2019;1:34-38. DOI: 10.31655/2307-3373-2019-1-44-49.

5. Royal College of Physicians. Allergy: the unmet need: a blueprint forbetter patient care. Report of a working party. London: RCP, 2003. Available from: www.bsaci. org/pdf/allergy_the_unmet_need.pdf (last accessed 5 March 2015) ic IgE by the Euroline method, there is a satisfactory agreement between the research results.

To evaluate a difference in the results of two systems for determining specific IgE to mugwort by Rida metho ds AllergyScreen and Euroline we conducted a comparative analysis according to the diagrams of Blend- Altman. The comparison results are shown in Picture 1.

First, the systematic error of the measurement results was $-3.01 \mathrm{ku} / \mathrm{l}$, which indicates the presence of a systematic difference. The distribution graph corresponds to the type of graphs of absolute systematic error. Second, the standard deviation of the difference was 15.5 , which is significantly compared to the values themselves. Third, there is no dependence of the measurement difference on the amount of specific IgE in the blood. In addition, part of the values do not fit within the confidence limits of $\pm 95 \%$.

Conclusions. Thus, the results of the two systems for the determination of specific IgE for mugwort allergen by the Rida AllergyScreen and Euroline methods do not fully correspond due to the systematic divergence of indicators.

There is good correspondence between the results of skin allergen testing and the detection of specific IgE by the Rida Allergyscreen method, and moderate correspondence between the results of skin allergen testing with the mugwort allergen and the detection of specific IgE by the Euroline method.
6. Landivar Encalada M, et al. How molecular diagnosis can change allergen-specific immunotherapy prescription in a complex area of pollen sensitization (Madrid, Spain). J Allergy Clin Immunol. 2012;129(2):248. DOI: https://doi.org/10.1016/j. jaci.2011.12.061.

7. Luengo O, et al. Structured assessment of component resolved diagnosis using a immunoassay platform for multiplex measurement of sIgE in multi-sensitised allergic patients. Proceedings of the European Academy of Allergy and Clinical Immunology (EAACI), 29th Congress, 5-9 June 2010, London, UK. Allergy. 2010;65:743.

8. Passalacqua G, Melioli G, Bonifazi F, Bonini S, Maggi E, Senna G, et al. The additional values of microarray allergen assay in the management of polysensitized patients with respiratory allergy. Allergy. 2013;68(8):1029-33. doi: 10.1111/ all.12194.
Надійшла до редакції: 22.11.2019 р.

Прийнято до друку: 27.11.2019 p.
A. Ye. Bogomolov

ORCID iD

https://orcid.org/0000-0002-5336-4858 